\title{
OD REDAKTORA NACZELNEGO
}

Przed dwudziestoma pięcioma laty wiele ludów europejskich radowało się upadkiem tzw. systemu sowieckiego, licząc na to - a byli i tacy, którzy wieszczyli „koniec historii” - że zapanuje wolność, nie będzie już napięć, a zwłaszcza nie będzie już wojen. Rychło okazało się, że najpierw na Bałkanach, a obecnie na Ukrainie pojawiły się napięcia, a nawet rozpętane zostały konflikty zbrojne. Ten, który wybuchł w połowie drugiej dekady XXI wieku, a który dotyczy dramatycznych wydarzeń na Ukrainie, jest o tyle istotny, $\dot{z} e$ - w pewnym zakresie inaczej niż na Bałkanach - wiąże się z przyłączeniem terytorium należącego uprzednio do jednego państwa do państwa drugiego; związany jest, co więcej, z ogólniejszą dyskusją o roli, jaką odgrywa dzisiaj kategoria „suwerenność”, i o podmiocie lub podmiotach, które miałyby być jej depozytariuszami w poszczególnych państwach.

Trwający, pod wieloma względami niebezpieczny konflikt rosyjsko-ukraiński skłonił nas do prac nad przygotowaniem specjalnego numeru „Politei”, w którym przedstawiane są ważne zjawiska polityczne, społeczne i kulturowe zachodzące w obu państwach. Wzorem ongiś ustalonym - realizowanym zarówno w numerach specjalnych poświęconych Litwie, Białorusi i Wenezueli - zaprezentowane w pierwszym woluminie numeru 34 „Studia ukraińskie” (redagowanym przez prof. Aleksieja Romaniuka ze Lwowa i dr. Piotra Bajora z Krakowa) zawierały teksty przygotowane wyłącznie przez uczonych z różnych ośrodków ukraińskich, zaś przedstawiane Czytelnikowi w drugim woluminie tego numeru „Studia rosyjskie” (zredagowane przez prof. Artura Demchuka z Moskwy, prof. Iwana Radikowa z Petersburga i prof. Andrzeja Dudka z Krakowa) - wyłącznie teksty przygotowane przez uczonych z różnych ośrodków rosyjskich. Do obu woluminów prezentowanego numeru „Politei” gromadziliśmy teksty dzięki owocnej współpracy pracowników Wydziału Studiów Międzynarodowych i Politycznych Uniwersytetu Jagiellońskiego w Krakowie z pracownikami wydziałów politologii najlepszych uczelni ukraińskich i rosyjskich w latach 2013-2015. Teksty do „Studiów rosyjskich" otrzymywaliśmy w okresie od czerwca 2013 do czerwca 2014 roku; ich 
Autorzy, podobnie jak Autorzy ukraińscy, przygotowali je z zamiarem publikacji w naszym czasopiśmie (nie informując dotąd, czy ogłosili je w innych publikacjach). Mamy nadzieję, że wiele uwag sformułowanych przez Autorów ukraińskich i rosyjskich przyczyni się do lepszego poznania złożonej sytuacji panującej w obu ich krajach, a zwłaszcza do pełniejszego uchwycenia niebezpiecznej relacji istniejącej między nimi.

Bogdan Szlachta 